\title{
The Influence on the Style of Teaching in Entrepreneurship Courses: A Study on Lecturer Against Students' Interest in Entrepreneurship
}

\author{
Pipin Sukandi ${ }^{1, *}$, Mohd Haizam Mohd Saudi ${ }^{1}$, Obsatar Sinaga ${ }^{2}$ \\ ${ }^{1}$ Widyatama University, Indonesia \\ ${ }^{2}$ Padjadjaran University, Indonesia
}

Copyright $\odot 2019$ by authors, all rights reserved. Authors agree that this article remains permanently open access under the terms of the Creative Commons Attribution License 4.0 International License

\begin{abstract}
Entrepreneurial concern matters to the Government of Indonesia. One way of the Government to make its citizens into self-employment by implementing entrepreneurship courses at the College. Entrepreneurship courses currently exist in various departments not only the Department of management and business alone but for all the majors taught entrepreneurship courses. As key in order for students attending entrepreneurship being an entrepreneur is a lecturer at the faculty. This research was to look at the influence of professors taught courses in entrepreneurship against the interest of the students to be an entrepreneur. Method in analyzing the data using the method of quantitative analysis and multiple regression linear. In this research that became the object of research is the students who are taking entrepreneurship courses at the Faculty of business and Management University of Widyatama. The research results show the influence of the teaching style turned out to be lecturer of entrepreneurship courses to student interest in entrepreneurship. So the lecturer of courses of entrepreneurship has an important role in increasing student interest in being an entrepreneur.
\end{abstract}

Keywords Style of Teaching, Entrepreneurship and Student Interest

\section{Introduction}

Many say that the sense of organization is a group of people who work together to achieve a goal. So too in a college where in it there is an awful lot of organizations included in the class. A college professor is enormous influence as its driving force of students in a class. The difference in the style of teaching and lecturers will then give rise to differences in student motivation also follow courses.
One of the subjects now exist in all departments is entrepreneurship courses. Here a lecturer who teaches courses in entrepreneurship role invites students not only works in a sense working office but worked as a creator of employment. The roles of professors in motivating students in classroom courses in entrepreneurship are instrumental to realizing the student becomes an entrepreneur.

According to the Badan Pusat Statistik (BPS) Indonesia population who became an entrepreneur in February 2014 recently reached 44.20 million people or about $0.18 \%$ of the total population in Indonesia which has reached approximately 240 million people. One of the causes is still at least a person that entrepreneurship is a graduate student who is still thinking of working at a company. This phenomenon is becoming a major challenge for a lecturer of entrepreneurship to change the mindset of prospective graduate students.

Basically that encourages entrepreneurship because someone has a desire to feel free of time in work, feel the freedom and financial freedom in risk. It is concerned between the lecturer of entrepreneurship with students who take courses in entrepreneurship to explain both in theory and practice field, but in fact not the least a teacher can only teach a course without motivating. Vice versa many teachers who can motivate students but can not teach. This deficiency be the attraction of researchers to combine both i.e. a teacher who can teach and motivate students in particular subjects of entrepreneurship. Thus the purpose of the government to realize the nation is able to create jobs can be a little helpful.

\section{Review of the Literature}

Someone chooses to become an entrepreneurial sometimes makes this is a last resort after failing in trying to work on a company. This certainly is the wrong sense. 
Gilad and Levin (1986) say two related theories between the motivation of being an entrepreneur. That is the theory of encouragement and attraction. The theory of encouragement saying that individuals there are negative impulses such as discontent in the works, the difficulty of finding a job, a salary that is not satisfactory and the work schedule that is not flexible. The pull theory argues that while individuals are drawn into the activities of seeking freedom, the fulfillment yourself, your own desired results and well-being. It is certainly that must be delivered by a teacher to students that there are in fact two human nature namely sense disappointed if not met his expectations and find satisfaction in order to cover the taste of disappointment. In the case of delivery by a teacher has to be conveyed in words which can be understood by students. Teaching lecturer then determines the motivation to act a student who listened to the explanations (Kip'ngetich, Osman \& Ali, 2018; Koumje, 2018; Kubat \& Dedebali, 2018).

While teaching appointment process can be analyzed as potential contained within protégé whose goal of finding and directing protégé into itself. Variations in the style of teaching is also badly needed to avoid student boredom in the absorption of a given theory lecturer (Hussein, 2017; Hubeis \& Affandi, 2017; Ihtiyaroglu \& Ates, 2018; Jabarullah and Hussain, 2018). The aim of this teaching variations is to attract attention and increase the protégé against the instructional materials, giving students the opportunity to develop talents and so on (Ahmed, Umrani, Qureshi \& Sarmad, 2018; Ali \& Haseeb, 2019; Haseeb, Abidin, Hye, \& Hartani, 2018; Haseeb., 2019; Suryanto, Haseeb, \& Hartani, 2018).

Variation of style of teaching includes several aspects include;

a. The sound variation which in this volume, intonation, tone, speed as well as the contents of the talks and the use of language.

b. The emphasis, this serves to focus the attention of the student on an aspect which is important.

c. The granting of time, it can be done to ask a few questions or to turn into a question of higher grades.

d. Contact point of view, staring eyes protégé can form positive relationships and avoid the loss of personality.

e. Hints of the face, the face is an instrument or a tool to convey a message or where and to enhance the emotional relationship.

f. The movement of limbs, head or hand movement can attract attention and can help in conveying the meaning of talk.

g. Move the position, can help attract the attention of students like walking to the back, from left to right or from a sitting position into a stand.

The purpose of the existence of variations in the style of teaching that is carried out by a professor to his protégé is to:

a. Increase and maintain the attention of the protégé against the relevance of the process of teaching and learning.

b. Providing opportunities chances of proper functioning of the motivation.

c. Forming a positive attitude towards a teacher (Lecturer).

d. Provide the possibility of choice and individual learning facilities.

e. Encourage protege to learn.

There are several kinds of technique teaching styles that can be used by a teacher in the classroom, including:

a. Classic style of teaching.

This teaching style is a teacher still dominates in the classroom without giving a chance to an active student to ask. So this style will hamper the development of students in the learning process.

b. Technological teaching style

This style requires an educator to hold on to a variety of media sources available. Professors teach by paying attention to the readiness of the students and always provide a stimulant to be able to answer all the question at hand.

c. Personalized teaching styles

This teaching style is one of the keys to successful achievement of learning for the student. These personalized teaching styles will always improve their learning and also always looked at his protégé kid like himself, so as not to force the student to be the same with his tutor.

d. Teaching style interaksional

Interaksional teaching style more emphasis dialogis with protégé as a form of dynamic interactions. Educator and student of interdependence, means that they are both the subject of learning and nothing is considered best or most ugly.

According to De Porter and Hernacki in Suparman (2009:64) style of teaching classification:

a. Visual Teaching Style

Where an educator in giving instruction using pictures, sketches, diagrams, graphs or illustrations related to the topic of discussion.

b. Auditory Teaching Style

Where an educator in giving instruction using an explanation directly all the time his tutor.

c. Kinesthetic Teaching Style

Where an educator in providing instruction to use physical activity as a subject that students learn.

Whereas the characteristics of an entrepreneur can be said to be successful (Pearce 1989:2), including:

a. Has a high commitment.

b. A strong Dorangan feat to achieve.

c. Orientation toward opportunities and goals.

d. Internal control Focus. 
e. Tolerance terhadao ambiguity.

f. Ability to solve problems.

g. The ability to face the failure effectively.

\section{Research Methods}

In this research, which provided the population are students who are taking entrepreneurship courses at the Faculty of Business and Management Widyatama University, Bandung.

In determining the sample, the author uses the method or methods of census sensal overall students who take courses in entrepreneurship in 5 classes or as many as 166 people.

Data collection techniques used is by charging the questionnaire. The questionnaire is a way of data collection by providing a list of questions to respondents in the hope it will give a response to the question. In this study a questionnaire using the closed and open questions. Variable measurement performed using likert scale. Besides using direct interview techniques to students (Iwuchukwu \& Iwuchukwu, 2018; Iwuchukwu, Ineji, \& Inyang, 2018; Kamau, Mwania \& Njue, 2018; Allam, 2018; Andriansyah et al., 2018; Manzuma-Ndaaba et al., 2018; Bagherpour \& Shamshiri, 2018; Tayebi et al., 2019).

There are two important terms that apply to a questionnaire that is valid and reliabelnya instruments that exist in the questionnaire, it is necessary for the extent to which the insturmen dikur can be used. So in this study, after gathering the questionnaires done then done test validity and reliability. The validity of a test is done by correlating each question with a total score of each variable.

Validity of the test results of each variable is as follows:

Table 1. Recap of the Validity of the Test Results of the Variable X (A Style of Teaching) Item-Total Statistik

\begin{tabular}{|l|l|l|l|}
\hline \multicolumn{1}{|c|}{ Item } & $\boldsymbol{t}_{\text {count }}$ & $\boldsymbol{t}_{\text {table }}$ & Result \\
\hline $\begin{array}{l}\text { Lecturer in taking decisions } \\
\text { have the absolute power }\end{array}$ & .501 & 0.153 & Valid \\
\hline $\begin{array}{l}\text { Lecturer in assigning processed, } \\
\text { freeing students choose group }\end{array}$ & .427 & 0.153 & Valid \\
\hline $\begin{array}{l}\text { The behavior of the lecturer } \\
\text { showed the direction to students } \\
\text { to entrepreneurship }\end{array}$ & .586 & 0.153 & Valid \\
\hline $\begin{array}{l}\text { The behavior of the lecturer } \\
\text { showed concern for the students } \\
\text { in the process of teaching }\end{array}$ & .584 & 0.153 & Valid \\
\hline $\begin{array}{l}\text { The behavior of the lecturer } \\
\text { gave freedom to students in the } \\
\text { suggested }\end{array}$ & .538 & 0.153 & Valid \\
\hline $\begin{array}{l}\text { The behavior of the lecturer } \\
\text { showed his ability in the } \\
\text { teaching of entrepreneurship }\end{array}$ & .596 & 0.153 & Valid \\
\hline $\begin{array}{l}\text { The lecturer showed the } \\
\text { behavior of proximity to the } \\
\text { student in the process of } \\
\text { teaching }\end{array}$ & .592 & 0.153 & Valid \\
\hline
\end{tabular}

Source: the questionnaire data processed
From the test above, it can be concluded that the entire item is a question of the variable $\mathrm{X}$ is valid in the state.

Table 2. Recap of the Validity of the Test Results of the Variable Y(Student Interest In Entrepreneurship) Item-Total Statistik

\begin{tabular}{|l|c|c|c|}
\hline \multicolumn{1}{|c|}{ Item } & $\boldsymbol{t}_{\text {count }}$ & $\boldsymbol{t}_{\text {table }}$ & Result \\
\hline $\begin{array}{l}\text { I was bored while attending } \\
\text { entrepreneurship }\end{array}$ & .114 & 0.153 & Valid \\
\hline $\begin{array}{l}\text { I have a sense of responsibility } \\
\text { in taking decisions }\end{array}$ & .584 & 0.153 & Valid \\
\hline I like a challenge & .570 & 0.153 & Valid \\
\hline I am a patient in troubleshooting & .523 & 0.153 & Valid \\
\hline I am glad to take the initiative & .570 & 0.153 & Valid \\
\hline I tend to follow your intuition & .539 & 0.153 & Valid \\
\hline I sometimes stubborn nature & .455 & 0.153 & Valid \\
\hline I am a confident in acting & .486 & 0.153 & Valid \\
\hline $\begin{array}{l}\text { I always thought the innovative } \\
\text { and creative }\end{array}$ & .537 & 0.153 & Valid \\
\hline $\begin{array}{l}\text { I am glad to live effectively and } \\
\text { efficiently }\end{array}$ & .615 & 0.153 & Valid \\
\hline I always oriented in the future & .608 & 0.153 & Valid \\
\hline $\begin{array}{l}\text { I was bored while attending } \\
\text { entrepreneurship }\end{array}$ & .480 & 0.153 & Valid \\
\hline $\begin{array}{l}\text { I have a sense of responsibility } \\
\text { in taking decisions }\end{array}$ & .494 & 0.153 & Valid \\
\hline
\end{tabular}

Source: the questionnaire data processed

From the test above, it can be concluded that the entire item is a question of a variable $\mathrm{Y}$ is in a valid state.

Reliability test is used to see the extent to which the instrument when used several times to measure the same object will generate the same data (Sugiyono 2009:109). In testing the reliability of researchers using the technique of dividing two (split-half method) odd-even where the researchers grouped score odd-numbered rounds as parts of the first and second parts as the even grain, according to Sugiyono (2009:109) that split the half method is a method to measure the level of consistency is an instrument that will be used to estimate the correlation between the two parts of the instrument with the overall instrument.

Reliability test results of each variable are as follows:

Table 3. Recap of the Reliability Test Results of Variable X (A Style of Teaching) Item-Total Statistik

\begin{tabular}{|l|l|l|l|}
\hline \multicolumn{1}{|c|}{ Item } & $\boldsymbol{t}_{\text {count }}$ & $\boldsymbol{t}_{\text {table }}$ & Result \\
\hline $\begin{array}{l}\text { Lecturer in taking decisions have } \\
\text { the absolute power }\end{array}$ & .791 & 0.60 & Reliable \\
\hline $\begin{array}{l}\text { Lecturer in assigning processed, } \\
\text { freeing students choose Group }\end{array}$ & .760 & 0.60 & Reliable \\
\hline $\begin{array}{l}\text { The behavior of the lecturer } \\
\text { showed the direction to students to } \\
\text { entrepreneurship }\end{array}$ & .795 & 0.60 & Reliable \\
\hline $\begin{array}{l}\text { The behavior of the lecturer } \\
\text { showed concern for the students in } \\
\text { the process of teaching }\end{array}$ & .852 & 0.60 & Reliable \\
\hline $\begin{array}{l}\text { The behavior of the lecturer gave } \\
\text { freedom to students in the } \\
\text { suggested }\end{array}$ & .713 & 0.60 & Reliable \\
\hline $\begin{array}{l}\text { The behavior of the lecturer } \\
\text { showed his ability in the teaching } \\
\text { of entrepreneurship }\end{array}$ & .803 & 0.60 & Reliable \\
\hline $\begin{array}{l}\text { The lecturer showed the behavior } \\
\text { of proximity to the student in the } \\
\text { process of teaching }\end{array}$ & .726 & 0.60 & Reliable \\
\hline
\end{tabular}

Source: the questionnaire data processed 
From the test above, it can be concluded that the entire item is a question of the variable $\mathrm{X}$ is in a State of reliability.

Table 4. Recap of the Reliability Test Results Variable Y (Student Interest In Entrepreneurship) Item-Total Statistik

\begin{tabular}{|c|c|c|c|}
\hline Item & $t_{\text {hitung }}$ & $t_{\text {tabel }}$ & Result \\
\hline $\begin{array}{l}\text { I was bored while attending } \\
\text { entrepreneurship }\end{array}$ & .760 & 0.60 & Reliable \\
\hline $\begin{array}{l}\text { I have a sense of responsibility } \\
\text { in taking decisions }\end{array}$ & .771 & 0.60 & Reliable \\
\hline I like a challenge & .728 & 0.60 & Reliable \\
\hline $\begin{array}{l}\text { I am a patient in } \\
\text { troubleshooting }\end{array}$ & .759 & 0.60 & Reliable \\
\hline I am glad to take the initiative & .717 & 0.60 & Reliable \\
\hline I tend to follow your intuition & .726 & 0.60 & Reliable \\
\hline I sometimes stubborn nature & .684 & 0.60 & Reliable \\
\hline I am a confident in acting & .646 & 0.60 & Reliable \\
\hline $\begin{array}{l}\text { I always thought the innovative } \\
\text { and creative }\end{array}$ & .735 & 0.60 & Reliable \\
\hline $\begin{array}{l}\text { I am glad to live effectively } \\
\text { and efficiently }\end{array}$ & .788 & 0.60 & Reliable \\
\hline I always oriented in the future & .773 & 0.60 & Reliable \\
\hline $\begin{array}{c}\text { I am glad against } \\
\text { entrepreneurship courses }\end{array}$ & .662 & 0.60 & Reliable \\
\hline $\begin{array}{c}\text { I am motivated and want to be } \\
\text { a businessman }\end{array}$ & .711 & 0.60 & Reliable \\
\hline I'd love to work at the company & .665 & 0.60 & Reliable \\
\hline
\end{tabular}

Source: the questionnaire data processed

From the test above, it can be concluded that the entire item is a question of a variable $\mathrm{Y}$ is in a State of reliability.

\section{The Result of the Research and the Discussion}

Style of teaching is one of the variables that have an impact on students' interest in entrepreneurship. In this section will be discussed regarding the influence of the style of teaching entrepreneurship student's interest against the professor.

To know how to influence the style of teaching entrepreneurship student interests against professors, have previously held test validity and reliability of the data obtained through questionnaires distributed to respondents. The research uses linear regression models. A good regression models must meet the absence of problems of classical assumptions in the model. If there is still the assumption that the regression model thus classic still has a bias. A classic assumption test is done as follows:

\subsection{Test for Normality}

Performed against each variable individually as well as the residual value of multivariate regression, testing was done using a graph of P-P Plot. Linear regression analysis results with a graph of a normal P-P Plot against the residual error of the regression model obtained showed the presence of a normal graph patterns, namely the existence of a distribution point that is located not far from the diagonal line.

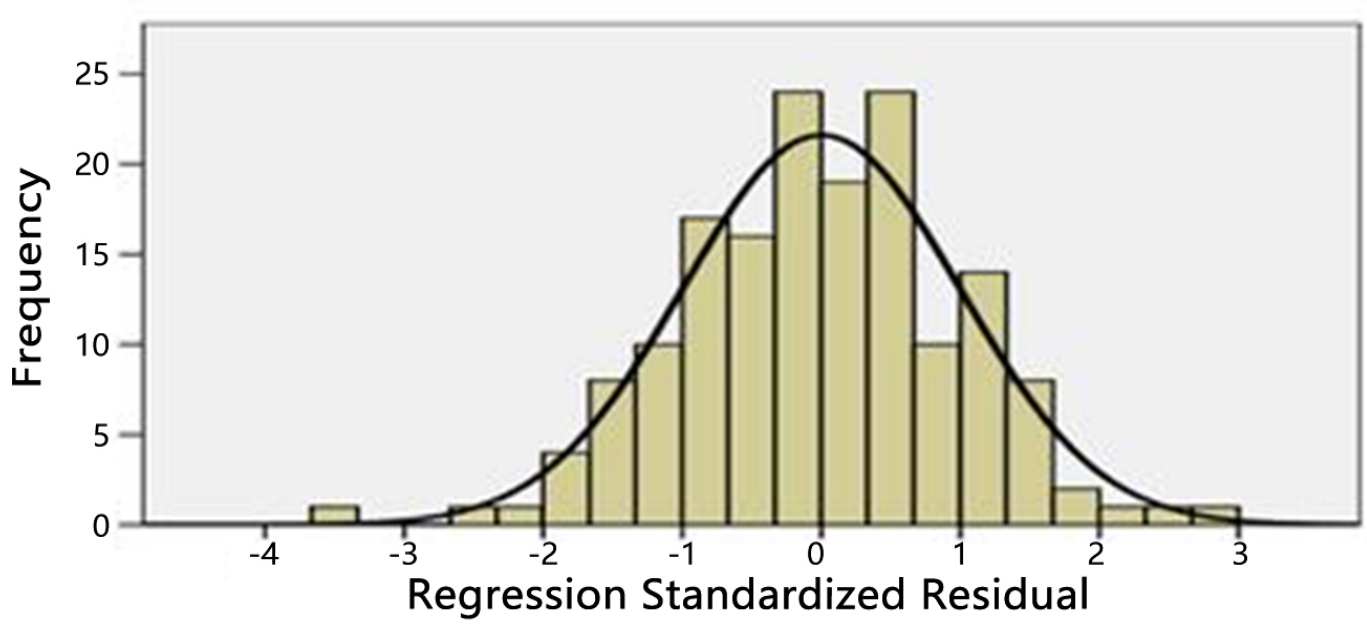

Source: The results of the processing of SPSS
Mean $=3.93 \mathrm{E}-16$

Std. Dev $=0.997$

$\mathrm{N}=162$

Figure 1. Histogram Dependent Variabel : Interest in student entrepreneurship 


\section{Normal P-P Plot of Regression Standardized Residual}

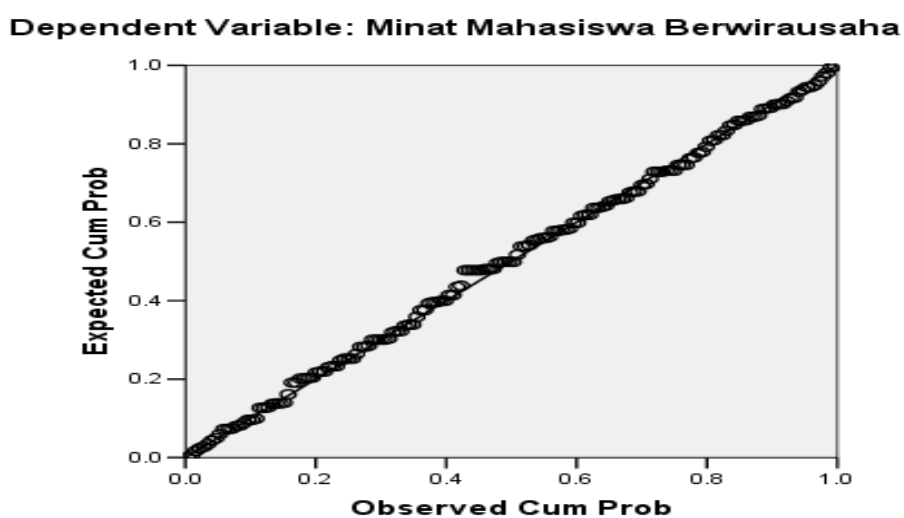

Source: The results of the processing of SPSS

Figure 2. Normality Diagram P-P Plot

In the regression model test of normality aims to test variable is a bully or residual has a normal distribution. In Figure 1 and 2 above shows that data is spread around the diagonal line and follow the direction of a diagonal line of aritnya meet the assumptions of normality test.

\subsection{Multiple Linear Regression Analysis}

Table 5. Regresion Model

Coefficients $^{\mathrm{a}}$

\begin{tabular}{|c|c|c|c|c|c|c|c|c|c|c|c|}
\hline \multirow[b]{2}{*}{ Model } & & \multicolumn{2}{|c|}{$\begin{array}{c}\text { Unstandardized } \\
\text { Coefficients }\end{array}$} & \multirow{2}{*}{$\begin{array}{c}\begin{array}{c}\text { Standardized } \\
\text { Coefficients }\end{array} \\
\text { Beta }\end{array}$} & \multirow[b]{2}{*}{$t$} & \multirow[b]{2}{*}{ Sig. } & \multicolumn{3}{|c|}{ Correlations } & \multicolumn{2}{|c|}{ Collinearity Statistics } \\
\hline & & B & Std. Error & & & & Zero-order & Partial & Part & Tolerance & VIF \\
\hline & (Constant) & 30,799 & 3,942 & & 7,813 &, 000 & & & & & \\
\hline & Gaya Mengajar Dosen & ,740 & , 138 & ,391 & 5,378 & ,000 & ,391 & ,391 & ,391 & 1,000 & 1,000 \\
\hline
\end{tabular}

a. Dependent Variable: Minat Mahasiswa Berwirausaha

Based on table 5 above, obtained thitung of 5,378 are then compared with the ttabel of 1,654 means style teaching positive effect against lecturers students ' interest in entrepreneurship.

\subsection{Coefficient of Determination}

It is used to measure how much the ability of the model in explaining the variation in the independent variable.

Based on table 6 Note that the coefficient of determination is obtained of 0153 . This means only $15.3 \%$ of lecturers teaching styles can affect students ' interest in entrepreneurship. Whereas, $84.7 \%$ influenced other variables such as the capital in entrepreneurship, networking and more.

Table 6. Coefficient of Determination

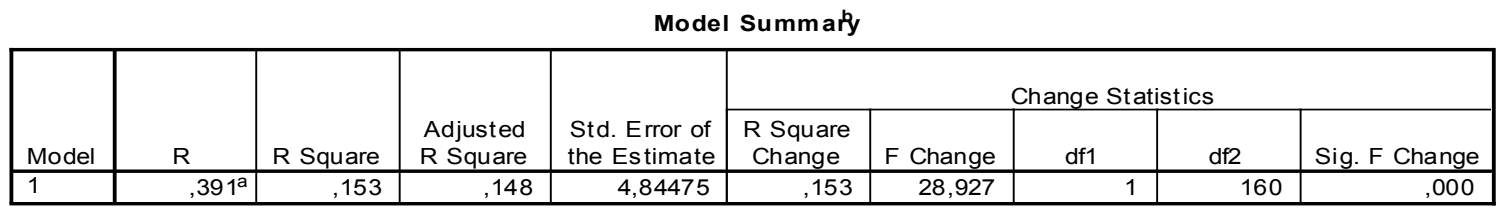

a. Predictors: (Constant), Gaya Mengajar Dosen

b. Dependent Variable: Minat Mahasiswa Berwirausaha 


\section{Conclusions and Implications}

Based on the results of the research on the influence of the style of professors taught courses in entrepreneurship against the interest of the student entrepreneurship, can be taken conclusions and implications as follows (Jabarullah and Hussain, 2019):

a. The style of teaching entrepreneurship courses lecturer not too influential significantly to student interest in entrepreneurship. But this is only limited to 5 classes are used as samples in the middle of the semester. So the need to do research for more than 5 classes and in the condition of the start or end of the semester.

b. in addition to the style of teaching entrepreneurship in students ' interest turned out to also have other things like the impact of the financial conditions for the network in the capital, make new friends, start a business in the personality traits and so forth.

c. Need for a curriculum that specifically supports the students in the practice of entrepreneurship theory after getting processed.

\section{Website}

www.repositiry.uksw.edu (diakses tanggal 08April 2018)

\section{REFERENCES}

[1] Adiprana, Andika (2014). Pengaruh gaya kepemimpinan dosen mata kuliah kewirausahaan terhadap kinerja mahasiswa pada prodi manajemen fakultas bisnis dan manajemen (fbm) universitas widyatama (utama). Fakultas Bisnis dan Manajemen Universitas Widyatama.

[2] Alma, Buchari. (2009). Kewirausahaan. Alfa Beta. Bandung.

[3] Drucker, Peter, (1996). Inovasi dan kewirausahaan. Erlangga. Jakarta.

[4] Gusti, Bima (2015). Faktor-faktor motivasi yang mempengaruhi minat mahasiswa berwirausaha. Fakultas Bisnis dan Manajemen Universitas Widyatama.

[5] Hubeis, A. V., \& Affandi, M. J. (2017). The Influence of Incentive towards their Motivation and Discipline (A Case Study at Rectorate of Andalas University, West Sumatera, Indonesia). Journal of Education and e-Learning Research, 4(4), 122-128.

[6] Hussein, L. M. (2017). The Effectiveness of Teaching Educational Research Course on the Development of Scientific Research Skills, Academic and Personal Integrity among Female Students of Al-Qassim University. International Journal of Asian Social Science, 7(5), 392-409.
[7] Ihtiyaroglu, N., \& Ates, Ö. T. (2018). Analyzing the Relationship between the Students' Stress-Coping Styles and School Attachment. Asian Journal of Education and Training, 4(4), 371-379.

[8] Iwuchukwu, G. C., \& Iwuchukwu, R. N. (2018). Sociolinguistics and Language Education in Nigeria. Global Journal of Social Sciences Studies, 4(1), 13-22.

[9] Iwuchukwu, G. C., Ineji, P. U., \& Inyang, E. (2018). Language, Communication, Poverty Eradication and the Fadama Projects in Nigeria. Global Journal of Social Sciences Studies, 4(1), 1-12.

[10] Jabarullah, N.H. and Hussain, H.I. (2018) Comparison of Higher TVET Education and 'Normal' Academic Education: The Determinants of Electrical Engineering Students' Performance, International Journal of Engineering \& Technology, 7 (4.29), 82-85.

[11] Jabarullah, N.H. and Hussain, H.I. (2019) The Effectiveness of Problem-Based Learning in Technical and Vocational Education in Malaysia, Education + Training, https://doi.org/10.1108/ET-06-2018-0129.

[12] Kamau, L. M., Mwania, J., \& Njue, A. K. (2018). Technology resources for teaching secondary mathematics: lessons from early and late adopters of technology in Kenya. Asian Journal of Contemporary Education, 2(1), 43-52.

[13] Kip'ngetich, K. J., Osman, A. A., \& Ali, M. M. (2018). John Deweyl's Experimentalism Philosophy and its Claim to the Kenyan Education System. Global Journal of Social Sciences Studies, 4(1), 30-38.

[14] Koumje, G. F. (2018). The didactics of bilingual education: Disciplinary teaching and language. International Journal of Educational Technology and Learning, 4(1), 8-12.

[15] Kubat, U., \& Dedebali, N. C. (2018). Opinions of Science Teachers for Classroom Management. Journal of Education and e-Learning Research, 5(2), 110-117.

[16] Sugiyono (2009). Metode penelitian bisnis Alfa Beta. Bandung

[17] Zulganef (2008). Metode penelitian sosial dan bisnis. Graha Ilmu. Jakarta.

[18] Allam, Z. (2018). Students' perception of quality in higher education: An empirical investigation. Management Science Letters, 8(5), 437-444.

[19] Andriansyah, A., Taufiqurokhman, T., \& Wekke, I. (2019). Responsiveness of public policy and its impact on education management: An empirical assessment from Indonesia. Management Science Letters, 9(3), 413-424.

[20] Manzuma-Ndaaba, N., Harada, Y., Nordin, N., Abdullateef, A., \& Rahim, A. (2018). Application of social exchange theory on relationship marketing dynamism from higher education service destination loyalty perspective. Management Science Letters, 8(10), 1077-1096.

[21] Bagherpour, M., \& Shamshiri, B. (2018). The effect of educational methods on creativity of pre-school children: A case study. Management Science Letters, 8(6), 717-724.

[22] Tayebi, S., Manesh, S., Khalili, M \& Sadi-Nezhad, S. (2019). The role of information systems in communication through social media. International Journal of Data and Network Science, 3(3), 245-268. 
[23] Ahmed, U., Umrani, W. A., Qureshi, M. A., \& Samad, A. (2018). Examining the links between teachers support, academic efficacy, academic resilience, and student engagement in Bahrain. INTERNATIONAL JOURNAL OF ADVANCED AND APPLIED SCIENCES, 5(9), 39-46.

[24] Ali, A., \& Haseeb, M. (2019). Radio frequency identification (RFID) technology as a strategic tool towards higher performance of supply chain operations in textile and apparel industry of Malaysia. Uncertain Supply Chain Management, 7(2), 215-226.

[25] Haseeb, M., Abidin, I. S. Z., Hye, Q. M. A., \& Hartani, N. H. (2018). The Impact of Renewable Energy on Economic Well-Being of Malaysia: Fresh Evidence from Auto Regressive Distributed Lag Bound Testing Approach. International Journal of Energy Economics and Policy, 9(1), 269-275.

[26] Suryanto, T., Haseeb, M., \& Hartani, N. H. (2018). The Correlates of Developing Green Supply Chain Management Practices: Firms Level Analysis in Malaysia. International Journal of Supply Chain Management, 7(5), 316. 